\title{
Dynamics of Allochthonous Organic Matter in a Tropical Brazilian Headstream
}

\author{
José Francisco Gonçalves Júnior * Juliana Silva França and Marcos Callisto \\ Laboratório de Ecologia de Bentos; Departamento de Biologia Geral; Instituto de Ciências Biológicas; \\ Universidade Federal de Minas Gerais; C. P. 486; jfjunior@icb.ufmg.br; 30161-970; Belo Horizonte - MG - Brasil
}

\begin{abstract}
The species composition of the riparian vegetation and the seasonal contribution of input and storage of fine and coarse particulate organic matter were assessed in a $3^{\text {rd }}$ order stretch. Fourteen tree species in the riparian zone were identified, with 3 species contributing with $68 \%$ of total litter input: Miconia chartacea Triana (43\%), Miconia cyathanthera Triana (16\%) and Erythroxylum pelletarianum St. Hil (9\%). The allochthonous input of coarse particulate organic matter (CPOM) was composed mainly by leaves (over 50\%). Species composition and the contribution of each plant species biomass for vertical, lateral and soil inputs and benthic stocks varied along the study period. The maximum values found in September, November and December coincided with the beginning of the rainy season. There were no differences between the allochthonous vertical and lateral inputs of CPOM to the stream. Differently to other studies, this result was probably due to the peculiar composition of stream's riparian vegetation at Serra do Cipó.
\end{abstract}

Key words: Riparian vegetation, input, standing stock, Cerrado, CPOM

\section{INTRODUCTION}

For streams, the importance of processing allochthonous inputs (e.g., leaves and wood) as the energetic basis for food webs in forested, temperate zones is well established (Webster et al., 1997). The ecological quality and functioning of rivers and streams are strongly influenced by both the riparian zone and by natural or anthropic alterations to the adjacent terrestrial systems linked by the riparian ecotone (Tabacchi et al., 1998). Low order streams with well developed riparian vegetation are considered heterotrophic, since they depend on the input of allochthonous organic matter as their main source of energy (Henry et al., 1994; Benfield, 1997; Suberkropp, 1998). Indeed, the protection of riparian vegetation and its associated benefits (e.g., filtration, regulation and maintenance of the conditions for survival and reproduction of the aquatic fauna) contribute to the equilibrium of lotic ecosystems (Lima, 1989).

The interaction of longitudinal (e.g., organic matter transport), lateral (e.g., transfer of organic matter stored in the riparian region), and vertical (e.g., leaf fall) inputs associated with temporal scales leads to a peculiar organic matter dynamics, with consequences on productivity, retention and deposit of different fractions of organic matter in streams (Allan, 1995; Jones, 1997; Webster and Meyer, 1997; Tabacchi et al., 1998). Seasonal variations in discharge, water velocity and litter inputs can influence available food resources and,

\footnotetext{
${ }^{*}$ Author for correspondence
} 
consequently, the density of detritivores (Boulton and Lake, 1992; Martinez et al., 1998).

Litter fall of deciduous forest in temperate regions occurs mainly in autumn (Stout, 1980). In Australian forests it begins in summer (Withers, 2001), but in the Brazilian savannah (Cerrado), the fall is greater during the dry season than in the wet season (Haase and Hirooka, 1998). Otherwise, there is little information about litter fall on Neotropical streams (Henry et al., 1994; Afonso et al., 2000), and the Cerrado organic matter dynamics (i.e., input, retention, process, and transport) is unknown. However, the transport of organic matter is strongly influenced by the rainy period, which affects the streambed structure, the allochthonous coarse particulate organic matter $(\mathrm{CPOM})$ and fine particulate organic matter (FPOM) ratios. It is also modified by hidrologic events, which generally occur for a few days or even hours (Webster et al., 1999; Bañuelos et al., 2004).

This study assessed the influence of riparian vegetation on the input and storage of allochthonous organic matter, and quantifies the seasonal variation category of CPOM (leaves, branches and others) and plant species in a $3^{\text {rd }}$ order stretch of headwater stream in Serra do Cipó
National Park, Minas Gerais State, southeastern Brazil.

\section{MATERIAL AND METHODS}

\section{Study Site}

The experiment was conducted along a $3^{\text {rd }}$ order stretch $(50$ meters $)$ of the Indaiá stream $\left(19^{\circ}\right.$ $16.4^{\prime} \mathrm{S}-43^{\circ} 31.2^{\prime} \mathrm{W}$ ), at $1,450 \mathrm{~m}$ altitude. The riparian vegetation of the selected stretch was a narrow swath less than $7 \mathrm{~m}$ wide on each bank, surrounded by rupestrian fields dotted with small shrubs (Table 1). The stream is located in Serra do Cipó National Park $(33,800$ ha) south of the Espinhaço mountain chain, which divides two important watersheds: São Francisco River and Doce River, in Minas Gerais state, southeast Brazil. The soil is latosol, deep and not very fertile. The vegetation consists of Cerrado (Brazilian savannah) species at the lower altitudes (up to $1,000 \mathrm{~m}$ a.s.l.), rocky fields in the highest reaches (above $1,000 \mathrm{~m}$ ) and riparian forest along the rivers, with about $30 \%$ of endemic plant species (Giulietti, 1996). The climate is classified as Cwb (Köppen), with rainy summers and dry winters.

Table 1 - Plant species present in the riparian vegetation in the 3rd order stretch of Indaiá stream (Serra do Cipó National Park, Brazil).

\begin{tabular}{lrr}
\multicolumn{1}{c}{ Species } & Family & Habit \\
\hline Augusta longifolia (Spreng.) & Rubiaceae & Shrub \\
Erytrhoxylum pelletarianum St. Hil & Erythroxylaceae & Shrub \\
Luxemburgia angustifolia Planch & Ochnaceae & Shrub \\
Miconia chartacea Triana & Melastomataceae & Arboreous \\
Miconia cyathanthera Triana & Melastomataceae & Shrub \\
Myrsine gardneriana A. DC. & Myrsinaceae & Arboreous \\
Myrcia guyanensis (Aubl.) DC. & Myrtaceae & Arboreous \\
Ocotea cf. lancifolia (Schott) Mez & Lauraceae & Arboreous \\
Podocarpus sellowii Klozsch ex Endl & Podocarpaceae & Arboreous \\
Protium brasiliense (Spreng.) Engl. & Burseraceae & Arboreous \\
Protium heptaphyllum (Aubl.) March & Burseraceae & Arboreous \\
Psychotria vellosiana Benth & Rubiaceae & Shrub \\
Sauvagesia sp. & Ochnaceae & Shrub \\
Baccharis ligustrina DC & Asteraceae & Shrub \\
\hline
\end{tabular}

\section{Sampling Design}

This study was carried out monthly from May (autumn-dry) to November 2001 (spring-rain). The onset of the wet season was marked by heavy storms, and a flush flow regime of the stream occurred, resulting in the interruption of field experiments through the loss of collecting traps. Benthic stock estimates began in June and ended 
in December. The input of CPOM to the soil was quantified using three nets $(1 \times 1 \mathrm{~m}, 5 \mathrm{~mm}$ mesh) placed randomly in the riparian zone. The vertical input of CPOM into the stream was quantified by placing 10 baskets $(0.26 \mathrm{~m}$ diameter each, suspended $3 \mathrm{~m}$ above the stream's surface and stretching from one bank to the other). The lateral input of CPOM was quantified using eight nets $\left(0.36 \mathrm{~m}^{2}, 5 \mathrm{~mm}\right.$ mesh $)$ randomly distributed along each bank. The CPOM stocked at the bottom of the stream (benthic stock) was collected randomly in triplicate each month with a Surber sampler $\left(0.27 \mathrm{~m}^{2}, 0.25 \mathrm{~mm}\right.$ mesh net). All the samples from these compartments were dried $\left(\mathrm{g} / \mathrm{m}^{2}\right)$ and qualified according to the species' composition. The CPOM was classified into three fractions: leaves, branches and others (fruits, flowers, seeds, and debris). The samples were washed in the laboratory over a $1 \mathrm{~mm}$ mesh sieve to separate the CPOM (material retried on sieve). Samples of CPOM were dried at $60^{\circ} \mathrm{C}$ for $72 \mathrm{~h}$. All the samples from the inputs and stock under study were weighed to the nearest $\mathrm{mg}$, burned for $4 \mathrm{~h}$ at $550^{\circ} \mathrm{C}$, and weighed again to determine the ashfree dry mass (AFDM).

\section{Data analysis}

ANOVA (two-way) were performed in order to compare differences among inputs and stock to every time (months) of each plant species. Differences of total vertical input, lateral input, soil input and, benthic stock were tested by the Kruskal-Wallis analysis of variance (one way on ranks) and compared by Tukey test (Zar, 1996).

\section{RESULTS}

The input (vertical, lateral and soil) and benthic stock of CPOM occurred throughout the studied period, and increased during the rainy period (spring season). The leaves were the most abundant fraction in the composition of inputs and stocks (over $50 \%$ ).
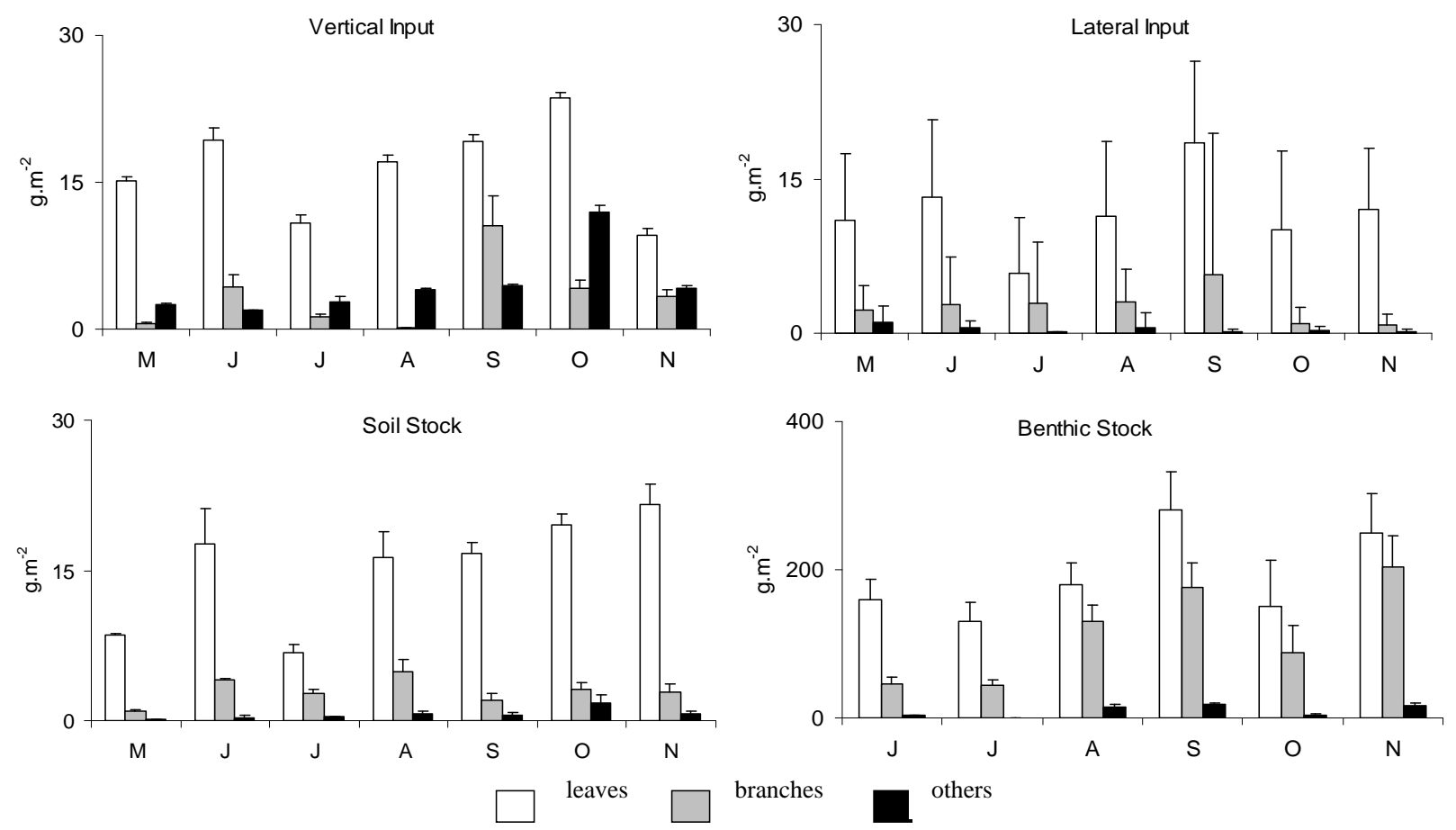

Figure 1 - Variation of the input and stock (means and standard deviation by AFDM $\mathrm{g} \mathrm{m}^{-2}$ ) of CPOM quantified into the fraction leaves, branches and others (flowers, seeds, and fruits) of the $3^{\text {rd }}$ order stretch of Indaiá stream.

The fruits, flowers, seeds and debris fractions (others) were the greater contribution in the vertical input throughout the studied period (1.510 g. $\left.\mathrm{m}^{-2}\right)$, especially in October $\left(12 \mathrm{~g} . \mathrm{m}^{-2}\right)$. The 
branch fraction was most representative in the benthic stock (20-200 g.m ${ }^{-2}$ ) (Fig. 1).

Significant differences were found in the input of plant species (ANOVA; vertical input: $\mathrm{F}_{13,84}=$ 18.759, lateral input: $F_{13,84}=9.0833$, soil input: $\mathrm{F}_{13,84}=9.18$, benthic stock: $\mathrm{F}_{13,84}=7.8489 ; \mathrm{p}<$ 0.0001) (Table 2). Podocarpus sellowii Klozsch ex Endl., Protium heptaphyllum (Aubl.) March and Myrcia guyanensis were the main contributors to the vertical input biomass. Miconia chartacea, Protium brasiliense and Ocotea cf. lancifolia were the most abundant in the lateral input. The species that most contributed to the soil input were Miconia chartacea, Podocarpus sellowii and Ocotea cf. lancifolia. As for the benthic stock, the species that contributed with the highest biomass were Myrcia guyanensis, Protium brasiliense and Podocarpus sellowii.

Table 2 - Species contribution (mean-M \pm standard deviation-SD in $\mathrm{g} \mathrm{AFDM} \cdot \mathrm{m}^{-2} \cdot \mathrm{month}^{-1}$ ) of all the inputs and stock in the $3^{\text {rd }}$ order stretch of Indaiá stream.

\begin{tabular}{|c|c|c|c|c|c|c|c|c|}
\hline \multirow{2}{*}{ Species } & \multicolumn{2}{|c|}{ Vertical Input } & \multicolumn{2}{|c|}{ Lateral Input } & \multicolumn{2}{|c|}{ Soil Stock } & \multicolumn{2}{|c|}{ Benthic Stock } \\
\hline & $\mathbf{M}$ & SD & $\mathbf{M}$ & SD & $\mathbf{M}$ & SD & $\mathbf{M}$ & SD \\
\hline Augusta longifolia (Spreng.) & 0.25 & 0.32 & 1.56 & 1.45 & 2.53 & 1.93 & 1.14 & 0.78 \\
\hline Baccharis ligustrina DC. & 0.01 & 0.03 & 0.19 & 0.30 & 0.01 & 0.02 & 0.33 & 0.61 \\
\hline Erytrhoxylum pelletarianum St. Hil & 0.23 & 0.24 & 1.33 & 0.76 & 2.51 & 2.15 & 1.64 & 1.42 \\
\hline Luxemburgia angustifolia Planch & 0.00 & 0.00 & 0.63 & 0.32 & 0.01 & 0.03 & 0.32 & 0.47 \\
\hline Miconia chartacea Triana & 0.41 & 0.55 & 8.75 & 5.79 & 9.86 & 6.31 & 1.15 & 0.66 \\
\hline Miconia cyathanthera Triana & 0.02 & 0.04 & 0.14 & 0.24 & 0.11 & 0.17 & 0.26 & 0.53 \\
\hline Myrsine gardneriana A. DC. & 0.09 & 0.14 & 0.81 & 1.23 & 1.99 & 1.82 & 1.32 & 0.63 \\
\hline Myrcia guyanensis (Aubl.) DC. & 1.17 & 0.78 & 3.49 & 1.94 & 1.64 & 0.81 & 3.51 & 2.35 \\
\hline Ocotea cf. lancifolia (Schott) Mez & 0.39 & 0.33 & 4.24 & 3.81 & 5.17 & 5.16 & 1.25 & 0.69 \\
\hline Podocarpus sellowii Klozsch ex Endl & 3.24 & 1.30 & 0.84 & 0.47 & 7.46 & 3.46 & 2.81 & 1.73 \\
\hline Protium brasiliense (Spreng.) Engl. & 0.65 & 0.29 & 4.45 & 2.36 & 2.61 & 1.03 & 3.08 & 1.20 \\
\hline Protium heptaphyllum (Aubl.) March & 1.40 & 0.74 & 1.33 & 1.16 & 0.81 & 1.55 & 1.74 & 1.24 \\
\hline Psychotria vellosiana Benth & 0.40 & 0.70 & 0.64 & 0.41 & 1.17 & 0.75 & 0.43 & 0.32 \\
\hline Sauvagesia sp. & 0.02 & 0.06 & 0.13 & 0.17 & 0.07 & 0.18 & 0.24 & 0.33 \\
\hline Other species & 0.39 & 0.54 & 4.09 & 2.41 & 5.08 & 3.05 & 11.1 & 3.76 \\
\hline
\end{tabular}

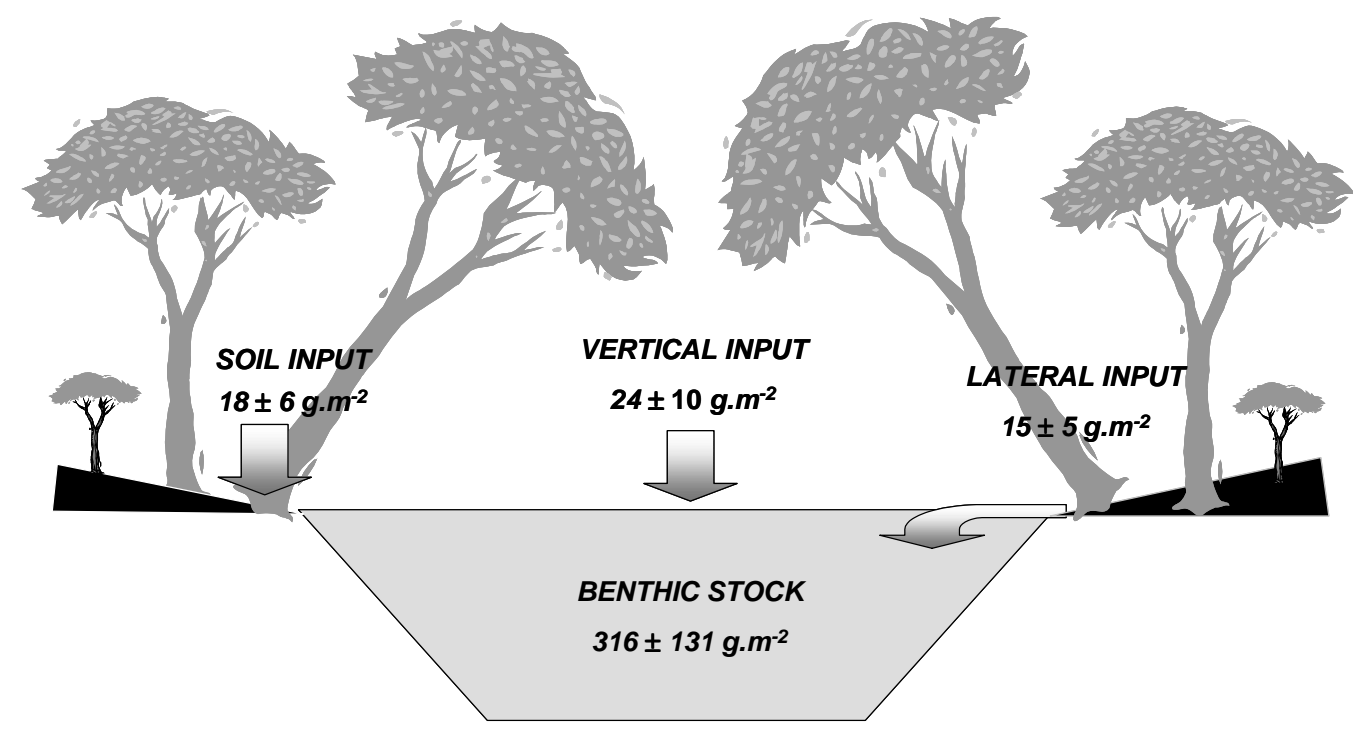

Figure 2 - Montly estimations of organic matter (AFDW) inputs and stock in the $3^{\text {rd }}$ order stretch of Indaiá stream. 
Eleven out of the 14 plant species contributed with more than $1 \mathrm{~g} \mathrm{~m}^{-2}$ month $^{-1}$ to the benthic stock.

Statistical differences (Kruskal-Wallis; $\mathrm{H}=9.899$, $\mathrm{p}=0.019)$ between benthic stock and the group vertical input, lateral input, and soil input (Tukey test, $\mathrm{p}<0.05$ ) were found.

The results obtained monthly indicated that the mean and standard deviation vertical input of organic matter was $24 \pm 10$ g.m $\mathrm{m}^{-2}$, the lateral input was $15 \pm 5$ g.m $\mathrm{m}^{-2}$, the soil input was $18 \pm 6$ g.m ${ }^{-2}$, and the benthic stock was $316 \pm 131$ g.m ${ }^{-2}$ (Fig. 2). In the benthic stock, the maximum CPOM values were found in September and November (474 and 470 g. $\mathrm{m}^{-2}$, respectively).

\section{DISCUSSION}

The genera Miconia, Myrcia and Ocotea are also common in the rain and semi-deciduous Brazilian Atlantic Forests (Oliveira-Filho and Fontes, 2000). Sharing species with other vegetal formations (e.g., Atlantic and Amazon Forest) is a common characteristic of riparian zones of the Cerrado biome, which are therefore characterized as dispersion corridors (Rodrigues and Leitão-Filho, 2001).

The contribution of each plant species biomass to vertical, lateral and soil inputs and stocks varied along the study period. We measured the soil and the lateral inputs of CPOM to determine the potential standing crop that enters the stream from the soil. Two possible explanations for the inputs can be presented. Riparian plant species lose their leaves during different periods of the year and riverine characteristics of the studied stretch (bank inclination and stability, soil type, seasonal discharge, etc.) would influence the direction and location where the allochthonous organic matter deposits (Fleituch, 2001, Artmann et al., 2003, Magana and Bretschko, 2003). Our findings also suggested that major stocks of organic matter from soil were transferred to the stream.

Species composition differed in the vertical, lateral and soil inputs, but the greatest input consistently came from leaves $(>50 \%)$, which was mainly influenced by the rainy season, when stronger winds and storms happen, as observed by Magana (2001). Related studies conducted in temperate and tropical areas have found that the litter fall usually consisted of leaves (Henry et al., 1994; Afonso et al., 2000; Swan and Palmer, 2004; Bañuelos et al., 2004; Pérez, et al., 2003). No differences were found between the allochthonous vertical and lateral inputs of CPOM to the stream. These findings did not corroborate those of other studies carried out in the state of São Paulo, Brazil (Henry et al., 1994; see Table 4 in Afonso et al., 2000) and in temperate regions (Wallace et al., 1997; Bañuelos et al., 2004), in which higher values and greater differences between vertical and lateral stream inputs were found.

Streams having well-developed riparian vegetation receive large quantities of organic matter and the input is reflected in the benthic stock (Bilby and Likens, 1980; Swanson et al., 1982). Benthic stocks in the Indaiá stream were higher than those reported for Eucalyptus (Bañuelos et al., 2004) and deciduous forests (Wallace et al., 1997). This was very likely due to the stream's capacity to accumulate benthic organic matter during the dry season, besides the year-round vertical and lateral inputs, associated with the low leaf decomposition rate (Gonçalves, 2005) in the Indaiá stream. The stream's low discharge also influenced the low transportation and high accumulation of organic matter on benthic stock (Maridet et al., 1995).

In summary, the allochthonous organic matter input to the Indaiá stream consisted basically of leaves and no was found difference among inputs (vertical and lateral). Contrary to other studies, this result was probably due to the peculiar composition of the riparian vegetation of altitudinal streams at Serra do Cipó.

\section{ACKNOWLEDGEMENTS}

The first author received a Ph.D. scholarship from $\mathrm{CNPq}$ and CAPES within the Graduate Program in Ecology, Conservation and Management of Wildlife in UFMG. This study received financial support from CNPq (Proc 472.328/01-8), FAPEMIG (Proc 182.303) and PADI-Project AWARE Foundation. Thanks are also due to the IBAMA and US Fish and Wildlife Service for logistic support. A. Salino and M.E.G. Sobral (Botany Department, ICB/UFMG), J.R. Pirani (IB/USP), R. Goldenberg (Dep Botânica/UFPR), K. Yamamoto (IB-UNICAMP) and J.N. Nakajima (IB/UFU) helped with the identification of plant species. We are also indebt to R. P. Martins, M. A. S. Graça, C. Canhoto, and M. M. Santos for their kindly reviews on previous versions of this manuscript. 


\section{RESUMO}

Foram determinadas as espécies que compõem a vegetação ripária e avaliada a variação sazonal da entrada e o estoque de matéria orgânica particulada grossa (MOPG) em um trecho de $3^{\mathrm{a}}$ ordem. Três espécies dentre 14 identificadas foram as mais abundantes na região ripária: Miconia chartacea Triana (43\%), Miconia cyathanthera Triana (16\%) and Erythroxylum pelletarianum St. Hil (9\%). A matéria orgânica particulada alóctone foi composta principalmente por folhas (acima de $50 \%$ ) Foi observado que MOPG e MOPF no estoque bêntico aumentou de julho a dezembro de 2001, sendo mais elevado em setembro, novembro e dezembro com o início da estação chuvosa. A composição de espécies e a biomassa de cada espécie no aporte de matéria orgânica vertical, lateral, no solo e estoque bêntico variaram ao longo do período estudado. Não foram encontradas diferenças significativas entre os aportes de matéria orgânica vertical, lateral e no solo. Este resultado contraria os encontrados em outros estudos, o que provavelmente expressa um caráter peculiar da vegetação ripária dos riachos de altitude na Serra do Cipó.

\section{REFERENCES}

Artmann, U.; Waringer, J. A. and Schagerl, M. (2003), Seasonal dynamics of algal biomass and allochthonous input os coarse particulate organic matter in a loworder sandstone stream (Weidlingbach, Lower Austria). Limnologica, 33, 77-91.

Afonso, A. A. O.; Henry R. and Rodella R. C. S. M. (2000), Allochthonous matter input in two different stretches of a headstream (Itatinga, São Paulo, Brazil). Braz. Arch. Biol. Technol., 43, 335-343.

Allan, D. J. (1995), Stream Ecology: structure and function of running waters. London: Chapman and Hall.

Benfield, E. F. (1997), Comparison of litterfall input streams. Stream Organic Matter Budgets. J. N. Amer. Benthol. Soc., 16, 104-108.

Bilby, R. E. and Likens, G. E. (1980), Importance of organic debris dams in the structure and function of stream ecosystems. Ecology, 61, 1107-1113.

Boulton, A. J. and Lake, P. S. (1992), Benthic organic matter and detritivorous macroinvertebrates in two intermittent streams in south-eastern Australian. Hydrobiologia, 241, 107-118.
Bañuelos, R.; Larrañaga, S.; Elosegi, A. and Pozo, J. (2004), Effects of eucalyptus plantations on CPOM dynamics in headwater streams: a manipulative approach. Arch. Hydrobiol., 159, 211-228.

Fleituch, T. (2001), Beech leaf breakdown and POM storage along an altitudinal stream gradient. Internat. Rev. Hydrobiol., 86, 515-525.

Giulietti, A. M. (1996), Flora: diversidade, distribuição geográfica e endemismo. In: Fernandes, G. W. (Ed.). Serra do Cipó: Ecologia e evolução. Rio de Janeiro: Vozes.

Gonçalves Jr., J. F. (2005), Decomposição de detritos foliares em riachos: composição química, invertebrados e microrganismos. Tese (Doutorado) Instituto de Ciências Biológicas, Universidade Federal de Minas Gerais, Belo Horizonte (MG).

Henry, R.; Uieda, V. S.; Afonso, A. A. O. and Kikuchi, R. M. (1994), Imput of allochthonous matter and structure of fauna in a Brazilian headstream. Internat. Rev. Theor. Limnol., 25, 1866-1870.

Jones Jr., J. B. (1997), Benthic organic matter storage in streams: influence of detrital import and export, retention mechanisms, and climate. Stream Organic Matter Budgets. J. N. Amer. Benthol. Soc., 16, 109-119.

Lima, W. P. (1989), Função hidrológica da mata ciliar. In: Simpósio sobre mata ciliar, São Paulo. Anais ... São Paulo: Fundação Cargill. pp. 25-42.

Magana, A. E. M. (2001), Litter inputs from riparian vegetations to streams: a case study of the Njoro River, Kenya. Hydrobiologia, 458, 141-149.

Magana, A. E. M. and Bretschko, G. (2003), Retention of coarse particulate organic matter on the sediments of Njoro River, Kenya. Internat. Rev. Hydrobiol., 88, 414-426.

Maridet, L.; Wasson, J. G.; Philippe, M. and Amoros, C. (1995), Benthic organic matter dynamics in three streams: riparian vegetation or bed morphology control. Arch. Hydrobiol., 132, 415-425.

Martinez, B.; Velasco, J.; Suárez, M. L. and VidalAbarca, M. R. (1998), Benthic organic matter dynamics in an intermittent stream in South-East Spain. Arch. Hydrobiol., 141, 303-320.

Oliveira-Filho, A. T. and Fontes, M. A. L. (2000), Patterns of floristic differentiation among Atlantic forests in southeastern Brazil and the influence of climate. Biotropica, 32, 793-810.

Pérez, C. A.; Armesto, J. J.; Torrealba, C. and Carmona, M. R. (2003), Litterfall dynamics and nitrogen use efficiency in two evergreen temperate rainforest of southern Chile. Aust. Ecol., 28, 591-600.

Rodrigues, R. R. and Leitão-Filho, H. F. (2001) Matas Ciliares: conservação e recuperação. 2. ed. São Paulo: Edusp.

Stout, J. R. (1980), Leaf decomposition rates in a Costa Rica lowland tropical rainforest stream. Biotropica, 12, 264-272. 
Suberkropp, K. (1998), Microorganisms and organic matter processing. In: Naiman, R. J. and Bilby, R. E. (Eds.). River Ecology and Management: lessons from the Pacific coastal ecoregion. New York: Springer Verlag. pp. 120-143.

Swan, A. M. and Palmer, M. A. (2004), Leaf diversity alters litter breakdown in a Piedmont stream. J. $N$. Amer. Benthol. Soc., 23, 15-28.

Tabacchi E.; Correl, D. L.; Hauer, R.; Pinay, G.; PlantyTabacchi, A. M. and Wissmar, R. C. (1998), Development, maintenance and role of riparian vegetation in the river landscape. Freshwat. Biol., 40, 497-516.

Wallace, J. B.; Eggert, S. L.; Meyer, J. L. and Webster, J. R. (1997), Multiple trophic levels of a forest stream linked to terretrial litter inputs. Science, 277, 102-104.

Webster, J. R. and Meyer, J. L. (1997), Organic matter budgets for streams: a synthesis. Stream Organic Matter Budgets. J. N. Amer. Benthol. Soc., 16, 141-161.
Webster, J. R.; Meyer, J. L.; Wallace, J. B. and Benfield, E. F. (1997), Organic matter dynamics in Hugh White Creek, Coweeta Hydrologic laboratory, North Carolina, USA. J. N. Amer. Benth. Soc., 16, 74-78.

Webster, J. R.; Benfield, E. F.; Ehrman, T. P., Schaeffer, M. A.; Tank, J. L.; Hutchens, J. J.; D'Angelo, D. J. (1999), What happens to allochthonous material that falls into streams? A synthesis of new and published information from Coweta. Freshwat. Biol., 41, 687-705.

Received: June 16, 2005; Revised: September 12, 2005; Accepted: August 03, 2006. 